\title{
Global Challenges in the Treatment of Gastroenterology and Hepatology Diseases
}

\author{
Prabhakar Reddy Veerareddy* \\ University College of Pharmaceutical Sciences, Palamuru University, Indi ${ }^{a}$
}

Submission: April 13, 2017; Published: April 28, 2017

"Corresponding author: Prabhakar Reddy Veerareddy, University College of Pharmaceutical Sciences, Palamuru University,

Mahabubnagar-509001, Telangana State, India, Email: vpreddyindia@gmail.com

\section{Opinion}

Every year, there are an expected 1.5 billion episodes of diarrhoea in worldwide [1]. Global burden of gastroenterological diseases in three major areas like Diarrhoea, Hepatitis B, and Helicobacter Pylori. No single intervention is sufficient to eliminate the global burden of enteric and diarrhoeal diseases. Diarrhoeal diseases are caused by a wide variety of pathogens. Diarrhoeal episodes are generally acute in nature. Sometimes, they can cause fluid and electrolyte loss from the small intestine. Oral rehydration solution (ORS) developed at the International Centre for Diarrhoeal Diseases Research in Bangladesh in 1968 [2]. WHO adopted the distribution of an ORS in 1975 [3]. In 2000, China introduced a monovalent lamb-derived live attenuated oral vaccine, but, the efficacy of this vaccine is not known [4]. Hepatitis B Virus (HBV) is the foremost hepatological health problem. Two billion people worldwide ere suffering with HBV [5]. Chronic infection is responsible for the burden of disease associated with HBV. The best example of the effectiveness of a HBV vaccination programme is started in Taiwan [6]. The Global Alliance for Vaccines and Immunization (GAVI) was founded in 1999. GAVI is a consortium between WHO, the World Bank, UNICEF and the Bill and Melinda Gates Foundation [7]. Fifty percent of the world's population is infected by $H$ pylori [8]. Epidemiological studies revealed that person to person transmission is likely to be via faecal-oral and oral-oral routes [9]. $90 \%$ of duodenal ulcers and $70 \%$ of gastric ulcers are associated with $\mathrm{H}$ pylori infection [10]. Metronidazole resistance is an increasing problem in worldwide [11]. H pylori infection is recognised as an important public health problem in the developing countries. Irritable bowel syndrome (IBS) is one of the most common functional gastro intestinal disorder [12]. IBS symptoms have a considerably negative impact on patients' quality of life [13]. Renzapride and Cilansetron are used for the treatment of patients with IBS. Other pharmacologic classes like Neutrophins and Tachychinin antagonists are also used for the treatment of IBS [14]. Immunization with enteric vaccines can reduce the burden of severe diarrhoea. Treatment based therapies should be included into global health strategies to reduce the burden of gastrenterology and hepatology diseases.

\section{References}

1. World Health Organization (WHO).

2. Guerrant RL, Carneiro-Filho BA, Dillingham RA (2003) Cholera, diarrhea, and oral rehydration therapy: triumph and indictment. Clin Infect Dis 37(3): 398-405.

3. (1994) ICDDR, B and ORS: the history of a miracle discovery. Glimpse 16(2-3): 3-4.

4. Ling-Qiao Z (2001) A rotavirus vaccine licensed in China. Health News 31: 1 .

5. World Health Organization (2004) Hepatitis B vaccines. Wkly Epidemiol Rec 79(28): 255-263.

6. Chien YC, Jan CF, Kuo HS, Chen CJ (2006) Nationwide hepatitis B vaccination program in Taiwan: effectiveness in the 20 years after it was launched. Epidemiol Rev 28: 126-135.

7. Martin JF, Marshall J (2003) New tendencies and strategies in international immunisation: GAVI and The Vaccine Fund. Vaccine 21(78): 587-592.

8. Torres J, Pérez-Pérez G, Goodman KJ, Atherton JC, Gold BD, et al. (2000) A comprehensive review of the natural history of Helicobacter pylori infection in children. Arch Med Res 31(5): 431-469.

9. Brown LM (2000) Helicobacter pylori: epidemiology and routes of transmission. Epidemiol Rev 22(2): 283-297.

10. Suerbaum S, Michetti P (2002) Helicobacter pylori infection. N Engl J Med 347: 1175-1186.

11. Malfertheiner P, Megraud F, O'Morain C, Bazzoli F, ElOmar E, et al (2007) Current concepts in the management of Helicobacter pylori infection: the Maastricht III Consensus Report. Gut 56(6): 772-781.

12. Drossman DA, Camilleri M, Mayer EA, Whitehead WE (2002) AGA technical review on irritable bowel syndrome. Gastroenterology 123(6): 2108-31.

13. Koloski NA, Talley NJ, Boyce PM (2009) The impact of functional Gastrointestinal disorders on quality of life. Am J Gastroenterol 95(1): 67-71. 
14. Berrada D, Lembo T (2003) Novel therapies in the treatment of irritable bowel syndrome. Expert Opin Investig Drugs 12(4): 635-645.
This work is licensed under Creative Commons Attribution 4.0 License

DOI: $10.19080 /$ ARGH.2017.04.555655

\section{Your next submission with Juniper Publishers} will reach you the below assets

- Quality Editorial service

- Swift Peer Review

- Reprints availability

- E-prints Service

- Manuscript Podcast for convenient understanding

- Global attainment for your research

- Manuscript accessibility in different formats

( Pdf, E-pub, Full Text, Audio)

- Unceasing customer service

Track the below URL for one-step submission https://juniperpublishers.com/online-submission.php 